\title{
Purification and characterization of an endopeptidase from Lactococcus lactis subsp. cremoris SK11
}

\author{
Graham G. Pritchard, ${ }^{1}$ Andrea D. Freebairn ${ }^{1}$ and Tim Coolbear ${ }^{2}$
}

Author for correspondence: Graham G. Pritchard. Tel : +64 6356 9099. Fax: +64 63505682.

\footnotetext{
1 Department of Chemistry and Biochemistry, Massey University, Palmerston North, New Zealand

2 New Zealand Dairy Research Institute, Palmerston North, New Zealand
}

\begin{abstract}
An endopeptidase has been purified from Lactococcus lactis subsp. cremoris SK11. The enzyme is a $70 \mathrm{kDa}$ monomer, strongly inhibited by the metalloproteinase inhibitors 1,10-phenanthroline and phosphoramidon but relatively insensitive to EDTA. It is not significantly inhibited by the thiol enzyme inhibitor $p$-chloromercuribenzoate nor by the serine protease inhibitor phenylmethylsulphonyl fluoride. The action of the endopeptidase in catalysing the hydrolysis of several peptide hormones has been studied and the hydrolysis products identified by sequence analysis. The enzyme catalyses hydrolysis of peptide bonds in which a hydrophobic amino acid (most commonly a Phe or Leu) residue occupies the position immediately C-terminal to the hydrolysed bond. It thus has a specificity very similar to that of thermolysin. Two of the oligopeptides produced during the early stages of $\beta$ casein digestion by the lactococcal cell-wall proteinases were hydrolysed by the endopeptidase, the others were resistant to hydrolysis. Cell fractionation studies have shown that the distribution of endopeptidase activity between the different cell fractions is the same as that of the intracellular marker enzyme fructose bisphosphate aldolase, and thus indicate a cytoplasmic location for the enzyme. These observations argue against a role for this enzyme in the early stages of casein breakdown by the lactococcal proteolytic system.
\end{abstract}

Keywords: Lactococcus lactis subsp. cremoris, endopeptidase, proteases, dairy microbiology

\section{INTRODUCTION}

The hydrolysis of milk proteins by dairy starter lactic acid bacteria involves the action of a cell-envelope-associated proteinase, various peptidases and transport systems for peptides and amino acids (Kok, 1990; Smid et al., 1991; Pritchard \& Coolbear, 1993; Tan et al., 1993). The cellenvelope-associated proteinase catalyses the partial hydrolysis of one or more of the casein components of bovine milk to a series of oligopeptide products, the nature of which has been well characterized (Monnet et al., 1989, 1992; Visser et al., 1988, 1991; Reid et al., $1991 \mathrm{a}, \mathrm{b})$. The subsequent degradation of these oligopeptides to provide the free amino acids required for starter growth is less clearly defined. Several peptidases have now been isolated from lactococci (Kok, 1990; Smid et al., 1991; Tan et al., 1993). Most of these are aminopeptidases which could potentially degrade the

Abbreviations: BTP, Bis-tris propane; $\rho C M B, \rho$-chloromercuribenzoate. large casein oligopeptides by systematic cleavage of amino acids or dipeptides from the $\mathrm{N}$-terminus. This would require some of the aminopeptidases to be located external to the cell membrane since large oligopeptides are probably not readily transported across the membrane (Law, 1978; Rice et al., 1978). However, current evidence on the cellular location of the aminopeptidases indicates that they are mostly located intracellularly (Tan et al., 1992; Exterkate et al., 1992; Nardi et al., 1991; Booth et al., 1990).

Compared to the well-defined characterization and classification of the aminopeptidase enzymes from lactococci and other lactic acid bacteria (Kok, 1990; Tan et al., 1993), the relationship of the various enzymes with endopeptidase activity which have been reported from lactic acid bacteria, under a variety of names and designations, is less clearly understood. Two different endopeptidases, designated LEP-I and LEP-II, were isolated from Lactococcus lactis subsp. cremoris H61 (Yan et al., 1987a, b). LEP-I was shown to be a $98 \mathrm{kDa}$ monomer, unable to 
hydrolyse $\alpha_{\mathrm{s} 1^{-}}, \beta$ - or $\kappa$-caseins or insulin B-chain but catalysing hydrolysis of smaller peptides such as bradykinin, angiotensin, neurotensin and the $\mathrm{N}$-terminal 23residue fragment from $\alpha_{\mathrm{s} 1}$-casein. LEP-II was reported to be a dimer of two identical $40 \mathrm{kDa}$ subunits catalysing hydrolysis of a wider range of oligopeptides including insulin B-chain, glucagon and two $\alpha_{\mathrm{s} 1}$-casein oligopeptides, although as with LEP-I, whole $\alpha_{\mathrm{s1}^{-}}, \beta$-, and $\kappa$-caseins were not hydrolysed. More recently an endopeptidase was isolated from L. lactis subsp. cremoris $\mathrm{Wg} 2$ (Tan et al., 1991) which, like LEP-II, could catalyse hydrolysis of insulin B-chain and glucagon although the particular bonds hydrolysed were not identified. However, it differed from LEP-II in its molecular mass $(70 \mathrm{kDa}$ for both the native and subunit molecular mass). This enzyme was shown, by immunoreactivity to a polyclonal antibody raised to the purified enzyme, to be present in several strains of lactococci (Tan et al., 1992). An apparently similar enzyme, designated a neutral oligoendopeptidase (NOP), has been described from $L$. lactis subsp. cremoris C13 (Baankreis, 1992). The nucleotide sequence of the gene (designated pepO) encoding an endopeptidase in L. lactis subsp. cremoris P8-2-47 has been determined (Mierau et al., 1993) and shown to have sequence homology to mammalian enkephalinase.

Other lactococcal enzymes with endopeptidase activity (apart from the cell-envelope-associated proteinase) include enzymes designated as intracellular proteinases (Desmazeaud \& Zevaco, 1976; Muset et al., 1989; Zevaco \& Desmazeaud, 1980). These enzymes differ from the endopeptidases described above in their ability to hydrolyse $\beta$-casein.

The present study describes the purification and properties of an endopeptidase from $L$. lactis subsp. cremoris SK11. A comparison of the specificity and other properties of this enzyme with those of previously studied lactococcal endopeptidases and 'proteinases' suggests that many of these enzymes have a very similar specificity of action in hydrolysing peptides and may therefore be related enzymes.

\section{METHODS}

Bacterial strain, growth conditions and harvest. Lactococcus lactis subsp. cremoris SK11 was obtained from the culture collection of the New Zealand Dairy Research Institute, Palmerston North, New Zealand (isolate number 5221). Bacterial cultures for enzyme purification were grown in a 40 litre fermenter in a lactose/peptone/yeast extract medium following the procedure described by Lloyd \& Pritchard (1991). Bacterial cells were harvested by centrifugation at the end of the exponential phase (approximately $6 \mathrm{~h}$ after inoculation), washed twice with cold $50 \mathrm{mM}$ phosphate buffer ( $\mathrm{pH} \mathrm{6.4)}$, and the washed pellets were stored frozen at $-15^{\circ} \mathrm{C}$ until required.

Enzyme assays. Endopeptidase activity was determined using the peptide hormone bradykinin as substrate. The rate of hydrolysis was followed by measuring the decrease in bradykinin concentration after separating substrate and products by reverse-phase HPLC. The standard assay mixture contained $80 \mu \mathrm{l}$ bradykinin $\left(0.5 \mathrm{mg} \mathrm{ml}^{-1}\right.$ in deionized water) and $20 \mu \mathrm{l}$ appropriately diluted enzyme solution in either $20 \mathrm{mM}$ phosphate buffer (pH 6.4) or $20 \mathrm{mM}$-Bis-tris propane (BTP) buffer
( $\mathrm{pH} \mathrm{6.4).} \mathrm{The} \mathrm{reaction} \mathrm{mixture} \mathrm{was} \mathrm{incubated} \mathrm{at} \mathrm{room} \mathrm{tem-}$ perature and, at appropriate times, $50 \mu \mathrm{l}$ samples were removed and added to $25 \mu \mathrm{l} 3 \%(\mathrm{v} / \mathrm{v})$ trifluoroacetic acid (TFA) to stop further reaction. The samples were centrifuged at $10000 \mathrm{~g}$ in a microcentrifuge (MSE, MicroCentaur) and then $50 \mu$ l of supernatant was injected onto a Vydac 218 TP C18 reverse-phase column (250 $\mathrm{mm} \times 4.6 \mathrm{~mm}$; Alltech Associates) linked to a Philips PU4100 HPLC system. Residual bradykinin was separated from the peptide products using the following elution conditions. Solution A contained $0.1 \%$ TFA in glass-distilled deionized water; solution $\mathrm{B}$ contained $0.08 \%$ TFA in acetonitrile. Elution was by a linear gradient of $5-40 \% \mathrm{~B}$ at $1 \mathrm{ml}$ $\mathrm{min}^{-1}$ over $15 \mathrm{~min}$. Peptides were detected by their absorbance at $220 \mathrm{~nm}$. The system was calibrated using known concentrations of bradykinin. One unit of endopeptidase activity is defined as that amount of enzyme catalysing the hydrolysis of $1 \mu \mathrm{mol}$ bradykinin $\min ^{-1}$.

Lysine aminopeptidase activity was measured using lysyl $p$ nitroanilide as substrate and following the rate of appearance of $p$-nitroaniline spectrophotometrically at $405 \mathrm{~nm}$. The reaction mixture contained: $780 \mu \mathrm{l} 100 \mathrm{mM}$ MES buffer (pH 6.8); $200 \mu \mathrm{l}$ lysine $p$-nitroanilide $(5 \mathrm{mM})$ and $20 \mu \mathrm{l}$ appropriately diluted enzyme. One unit of enzyme is defined as that amount catalysing the formation of $1 \mu \mathrm{mol} p$-nitroaniline $\mathrm{min}^{-1}$.

Fructose-1,6-bisphosphate aldolase activity was measured essentially according to the procedure of Crow \& Thomas (1982).

Enzyme purification. All steps, except where specified otherwise, were carried out at a temperature of $0-4{ }^{\circ} \mathrm{C}$. Approximately $100 \mathrm{~g}$ frozen cells (collected from about $7.5 \mathrm{l}$ of culture) were thawed and resuspended in $170 \mathrm{ml} 20 \mathrm{mM}$ phosphate buffer ( $\mathrm{pH} \mathrm{6.4).} \mathrm{Bacterial} \mathrm{cells} \mathrm{were} \mathrm{disrupted} \mathrm{by} \mathrm{a} \mathrm{single}$ passage through a French pressure cell operated at $55 \mathrm{MPa}$. The resulting homogenate was centrifuged at $27000 \mathrm{~g}$ for $15 \mathrm{~min}$ and the supernatant collected. The supernatant was loaded onto a column $(3.5 \mathrm{~cm} \times 17 \mathrm{~cm})$ of DEAE-cellulose (Whatman DE23) equilibrated with $10 \mathrm{mM}$ sodium phosphate buffer (pH 6.4). The column was washed with $100 \mathrm{ml} 10 \mathrm{mM}$ sodium phosphate buffer ( $\mathrm{pH} \mathrm{6.4)} \mathrm{containing} 0.1 \mathrm{M} \mathrm{NaCl}$ and then bound protein was eluted with a linear $0 \cdot 1-0.6 \mathrm{M} \mathrm{NaCl}$ gradient using a total elution volume of $500 \mathrm{ml}$ and a flow rate of $1.2 \mathrm{ml}$ $\min ^{-1}$. Fractions containing high endopeptidase (bradykininhydrolysing) activity (eluting between 0.4 and $0.6 \mathrm{M} \mathrm{NaCl}$ ) were pooled and concentrated to a volume of $5-10 \mathrm{ml}$ by ultrafiltration through a PM 30 Diaflo membrane (Amicon). The concentrated sample was loaded onto a column $(2.6 \mathrm{~cm} \times 90 \mathrm{~cm})$ of Sephacryl S300 equilibrated with $20 \mathrm{mM}$ BTP buffer (pH 6.0) containing $0.1 \mathrm{M} \mathrm{NaCl}$ and eluted with the same buffer at a flow rate of $0.2 \mathrm{ml} \mathrm{min} \mathrm{m}^{-1}$. Fractions with high endopeptidase activity (eluting at $280-330 \mathrm{ml}$ ) were pooled and concentrated to less than $10 \mathrm{ml}$ by ultrafiltration. The concentrated fractions were then loaded onto a MonoQ HR 10/10 FPLC column (Pharmacia) equilibrated with $20 \mathrm{mM}$ BTP buffer (pH 6.5) and operated at room temperature. The column was washed with approximately $10 \mathrm{ml}$ equilibration buffer and bound protein was then eluted with a linear $0-1 \mathrm{M} \mathrm{NaCl}$ gradient over $40 \mathrm{~min}$ at a flow rate of $2 \mathrm{ml} \mathrm{min}^{-1}$. Fractions containing high endopeptidase activity were pooled and dialysed for $3 \mathrm{~h}$ against $20 \mathrm{mM}-\mathrm{BTP}$ buffer ( $\mathrm{pH} \mathrm{6.5)}$ containing $3 \mathrm{M} \mathrm{NaCl}$. The dialysed solution was loaded onto a $0.7 \mathrm{~cm} \times 6.5 \mathrm{~cm}$ column of phenyl-Sepharose equilibrated with the $20 \mathrm{mM}$ BTP (pH 6.5) containing $3 \mathrm{M} \mathrm{NaCl}$, the column was washed with approximately $50 \mathrm{ml}$ of equilibration buffer and enzyme eluted with a linear 3-0 $\mathrm{M} \mathrm{NaCl}$ gradient using a total elution volume of $240 \mathrm{ml}$ and a flow rate of $0.5 \mathrm{ml} \mathrm{min} \mathrm{min}^{-1}$. Contaminating proteins were eluted in the wash buffer, while the endopeptidase activity bound to the phenyl-Sepharose 
and was eluted as a homogeneous protein between 1.75 and $1 \mathrm{M} \mathrm{NaCl}$. Active fractions were pooled and concentrated by ultrafiltration using a Centricon 10 (Amicon) microconcentrator.

Protein determination. Protein concentration was measured using the bicinchoninic acid method of Smith et al. (1985) with bovine serum albumin as the standard.

Polyacrylamide gel electrophoresis (PAGE). Samples for analysis by SDS-PAGE were prepared by boiling with an equal volume of $0.125 \mathrm{M}$ Tris $/ \mathrm{HCl}(\mathrm{pH} 6.8)$ containing $4 \%(\mathrm{w} / \mathrm{v})$ SDS, $20 \%(\mathrm{v} / \mathrm{v})$ glycerol and $10 \%(\mathrm{v} / \mathrm{v}) \beta$-mercaptoethanol. SDS-PAGE was carried out according to the procedure of Laemmli (1970).

Determination of molecular mass. The molecular mass of the denatured monomer was determined using SDS-PAGE with the following proteins as standards: myosin $(205 \mathrm{kDa}), \beta$ galactosidase $(116 \mathrm{kDa})$, phosphorylase $b(97 \cdot 4 \mathrm{kDa})$, bovine serum albumin $(66 \mathrm{kDa})$, egg albumin $(45 \mathrm{kDa})$ and carbonic anhydrase $(29 \mathrm{kDa})$. The molecular mass of the native purified protein was determined from its elution volume from a Superose 12 gel permeation column (Pharmacia) eluted with $20 \mathrm{mM}$ BTP (pH 6.5) containing $0.15 \mathrm{M} \mathrm{NaCl}$ at a flow rate of $0.5 \mathrm{ml} \mathrm{min}^{-1}$. The following proteins were used as standards: $\beta$-amylase $(200 \mathrm{kDa})$; alcohol dehydrogenase $(150 \mathrm{kDa})$; bovine serum albumin $(66 \mathrm{kDa})$, carbonic anhydrase $(29 \mathrm{kDa})$, cytochrome $c$ $(12 \cdot 4 \mathrm{kDa})$.

$\mathrm{N}$-terminal sequence analysis. The $\mathrm{N}$-terminal amino acid sequence of the purified enzyme was determined by the automated Edman method using a gas-phase protein sequencer (Applied Biosystems $470 \mathrm{~A}$, with a $120 \mathrm{~A}$ PTH analyser).

Isolation and identification of peptide products of hydrolysis. The products of peptide hydrolysis by the purified endopeptidase were separated by HPLC using the apparatus and procedure described above for bradykinin (see Enzyme assays). Peptide peaks were collected and dried under vacuum. Peptides were identified by sequence analysis.

Cell fractionation. Bacteria were grown in reconstituted skim milk and harvested following the procedures described by Coolbear et al. (1992a). The harvested cells were separated into 'cell-wall lysate', 'cytoplasmic' and 'particulate' fractions using lysozyme plus mutanolysin to solubilize cell wall material and sucrose as osmostabilizer following the procedures described by Crow et al. (1993).

Materials. Bradykinin, neurotensin, insulin B-chain, metenkephalin and other small peptides were obtained from Sigma, as were other enzyme assay substrates. Oligopeptides produced by digestion of $\beta$-casein by purified cell-envelope-associated proteinases from L. lactis subsp. cremoris strains H2 and SK11 were isolated and identified as described by Reid et al. (1991b). Glycerol-3-phosphate dehydrogenase/triosephosphate isomerase was from Boehringer. Angiotensin was synthesised by $\mathrm{Dr}$ D. Engelbretsen of the Massey University Separation Science Unit. DEAE-cellulose DE23 was from Whatman Biochemicals, and all other column matrices and pre-packed columns were from Pharmacia. Acetonitrile and 2-propanol were HPLC-grade solvents from either BDH or Mallinckrodt. Yeast extract was from Gibco and Trypticase peptone from BBL.

\section{RESULTS AND DISCUSSION}

\section{Purification}

A typical purification is summarized in Table 1. The use of hydrophobic interaction chromatography on phenylSepharose was particularly effective in removing protein contaminants at the final stage, yielding a virtually homogeneous protein as determined by SDS-PAGE (Fig. 1).

\section{Molecular mass}

The subunit molecular mass, estimated from three separate SDS-polyacrylamide gels, was $69 \cdot 5 \pm 1 \cdot 2 \mathrm{kDa}$. This is in agreement with the value of $70 \mathrm{kDa}$ reported by Tan et al. (1991) for the molecular mass of the endopeptidase from $L$. lactis subsp. cremoris $\mathrm{Wg} 2$ and with the value of $71.5 \mathrm{kDa}$ calculated from the gene sequence for the endopeptidase from $L$. lactis subsp. cremoris P8-2-47 (Mierau et al., 1993). The native molecular mass determined by gel permeation was $93 \mathrm{kDa}$ (two separate determinations agreeing within $\pm 2 \mathrm{kDa}$ ). Thus this method results in an overestimation of the molecular mass. This is of interest since the mass of the intracellular proteinase purified from $L$. lactis subsp. lactis NCDO 763 (Muset et al., 1989) was also found to be $93 \mathrm{kDa}$ by gel permeation. A value of $80 \mathrm{kDa}$ (also determined by gel permeation) was reported for the LEP-II endopeptidase from L. lactis subsp. cremoris H61 by Yan et al. (1987a) although the subunit molecular mass of this enzyme, determined by SDS-PAGE, was only $40 \mathrm{kDa}$, indicating a dimeric native enzyme.

\section{$\mathrm{N}$-terminal sequence}

The sequence of the first 20 amino acid residues of the purified endopeptidase was determined (Table 2) except for the initial $\mathrm{N}$-terminal residue which could not be unambiguously identified. This $\mathrm{N}$-terminal sequence is identical to that predicted from the nucleotide sequence for the endopeptidase from $L$. lactis subsp. cremoris P8-247 (Mierau et al., 1993). However, it shows almost no homology with the $\mathrm{N}$-terminal sequence determined for LEP-II from L. lactis subsp. cremoris $\mathrm{H} 61$ by $\mathrm{Yan}$ et al. (1987a) except for the three residues which are the same in both sequences (see Table 2).

\section{pH dependence}

The $\mathrm{pH}$ dependence of the endopeptidase using the peptide metenkephalin as substrate (as used in the work of Tan et al., 1991) showed a simple $\mathrm{pH}$ profile with an optimum value of around 6.0 . This is in agreement with values reported for other lactococcal endopeptidases (Desmazeaud \& Zevaco, 1976; Yan et al., 1987a; Tan et al., 1991). However, when the $\mathrm{pH}$ dependence was studied using bradykinin as the peptide substrate, high enzyme activity was maintained over the range from $\mathrm{pH} 6.0$ to 9.5 . No difference in the bradykinin hydrolysis products was observed over this $\mathrm{pH}$ range. The reason for this difference in $\mathrm{pH}$ profiles using the two different substrates is unknown.

\section{Effect of proteinase inhibitors}

The sensitivity of the endopeptidase purified in the present study to various proteinase inhibitors (Table 3 ) was similar in most respects to previously reported findings on 
Table 1. Purification of an endopeptidase from L. lactis subsp. cremoris SK11

The results presented are for a purification from $75 \mathrm{~g}$ wet wt of cells.

\begin{tabular}{|c|c|c|c|c|c|c|c|}
\hline Purification step & $\begin{array}{c}\text { Protein } \\
\text { concn } \\
\left(\mathrm{mg} \mathrm{ml}^{-1}\right)\end{array}$ & $\begin{array}{l}\text { Total } \\
\text { protein } \\
\text { (mg) }\end{array}$ & $\begin{array}{c}\text { Activity } \\
\text { (units } \mathrm{ml}^{-1} \text { ) }\end{array}$ & $\begin{array}{c}\text { Total } \\
\text { activity } \\
\text { (units) }\end{array}$ & $\begin{array}{c}\text { Specific } \\
\text { activity } \\
\text { (units } \mathbf{m g}^{-1} \text { ) }\end{array}$ & $\begin{array}{c}\text { Purification } \\
\text { (-fold) }\end{array}$ & $\begin{array}{c}\text { Yield } \\
(\%)\end{array}$ \\
\hline Crude extract & $37 \cdot 5$ & 3700 & $3 \cdot 4$ & $256 \cdot 7$ & $0 \cdot 085$ & 1 & 100 \\
\hline DEAE-cellulose & $50 \cdot 6$ & 359 & $14 \cdot 5$ & $97 \cdot 3$ & $0 \cdot 271$ & $3 \cdot 15$ & 37 \\
\hline Sephacryl S300 & $12 \cdot 2$ & 73 & $2 \cdot 4$ & $27 \cdot 1$ & $0 \cdot 371$ & $4 \cdot 3$ & 10 \\
\hline MonoQ & 6.8 & $9 \cdot 8$ & $4 \cdot 9$ & $13 \cdot 0$ & $1 \cdot 32$ & $16 \cdot 0$ & 5 \\
\hline Phenyl-Sepharose & 0.52 & $0 \cdot 2$ & $6 \cdot 1$ & $2 \cdot 5$ & $12 \cdot 5$ & 147 & 1 \\
\hline
\end{tabular}

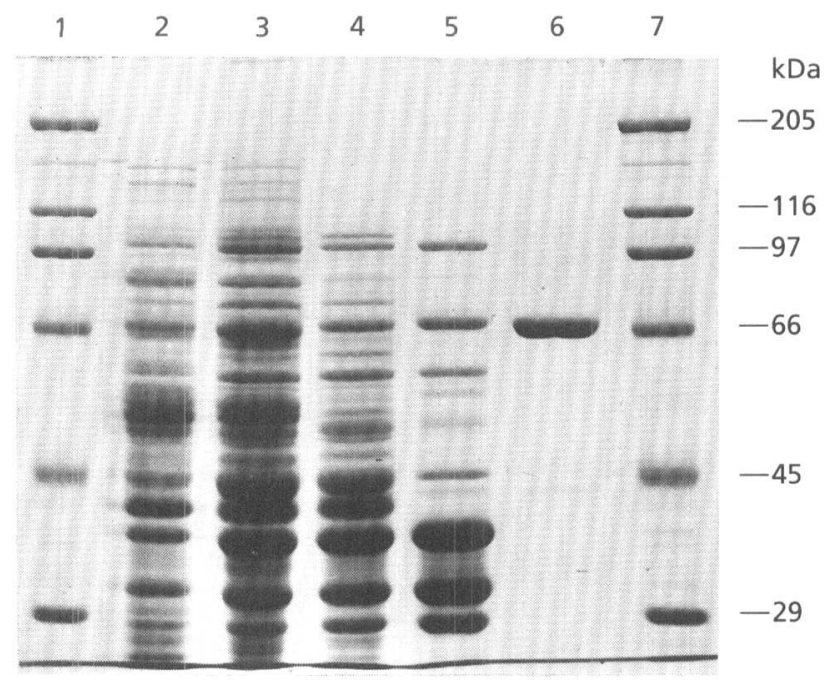

Fig. 1. SDS-PAGE showing purification of an endopeptidase from $L$. lactis subsp. cremoris SK11. Lanes 1 and 7, molecular mass standards; lane 2, crude cell extract; lane 3, pooled fractions from DEAE-cellulose column; lane 4, pooled fractions from Sephacryl $\$ 300$ column; lane 5 , active fractions from MonoQ column; lane 6 , active fractions from phenyl-Sepharose column.

the inhibition of lactococcal endopeptidases. However, a significant difference was the inability of EDTA (even at $10 \mathrm{mM}$ ) to inhibit the enzyme to less than $60 \%$ of the control activity, although activity was completely inhibited by two other metalloproteinase inhibitors, phosphoramidon $(0.1 \mathrm{mM})$ and 1,10 -phenanthroline $(1 \mathrm{mM})$. Previous studies on lactococcal endopeptidases
Table 3. Effect of protease inhibitors on activity of an endopeptidase from L. lactis subsp. cremoris SK11

The enzyme was preincubated for $30 \mathrm{~min}$ in the presence of inhibitor at the concentration shown and then the reaction was started by addition of substrate. Final inhibitor concentrations after addition of substrate were $60 \%$ of the concentrations shown.

\begin{tabular}{|lc|}
\hline Inhibitor & $\begin{array}{c}\text { Activity } \\
\text { (percentage of } \\
\text { uninhibited } \\
\text { control) }\end{array}$ \\
\hline EDTA $(10 \mathrm{mM})$ & 62 \\
o-Phenanthroline $(1 \mathrm{mM})$ & 0 \\
Phosphoramidon $(0 \cdot 1 \mathrm{mM})$ & 0 \\
pCMB $(1 \mathrm{mM})$ & 89 \\
PMSF $(1 \mathrm{mM})$ & 83 \\
\hline
\end{tabular}

(Tan et al., 1991; Yan et al., 1987a, b) have reported strong inhibition of endopeptidase activity by $1 \mathrm{mM}$ EDTA. Muset et al. (1989) found that the phosphoramidonsensitive intracellular proteinase from L. lactis subsp. lactis NCDO 763 was inhibited to only $58 \%$ of the control level by $1 \mathrm{mM}$ EDTA at $\mathrm{pH}$, although inhibition increased at lower $\mathrm{pH}$ values. The endopeptidase from $L$. lactis subsp. cremoris $\mathrm{C} 13$ was found to be only partially inhibited by $1 \mathrm{mM}$ EDTA and to require $10 \mathrm{mM}$ EDTA to achieve complete inhibition (Baankreis, 1992). In the present study, prolonged incubation of the enzyme with EDTA (10 mM), prior dialysis of the enzyme to remove or reduce the content of bound metal ions, variation of

Table 2. N-terminal amino acid sequences of lactococcal endopeptidases

\begin{tabular}{|cc|}
\hline Endopeptidase* & N-terminal sequence \\
\hline $\begin{array}{l}\text { (a) } \\
\text { (b) }\end{array}$ Phr-Arg-Ile-Gln-Asp-Asp-Leu-Phe-Ala-Thr-Val-Asn-Ala-Glu-Trp-Leu-Glu-Asn-Ala-Glu-Ile ... \\
(c) & ?-Phe-Thr-Leu-Pro-Glu-Leu-Pro-Tyr-Ala-Pro-Asn-Ala-Leu-Glu-Phe-Phe-Cys-Met...
\end{tabular}

* (a) Endopeptidase purified from L. lactis subsp. cremoris SK11 in the present study; (b) endopeptidase PepO from L. lactis subsp. cremoris P8-2-47 (Mierau et al., 1993); (c) endopeptidase LEP II from L. lactis subsp. cremoris H61 (Yan et al., 1987a). 
Table 4. Peptide bonds hydrolysed in hormone peptides by the endopeptidase from L. lactis subsp. cremoris SK 11

Peptides $(150-160 \mu \mathrm{g})$ were incubated with purified endopeptidase $(1-4 \mu \mathrm{g}$ protein in $20 \mathrm{mM} \mathrm{BTP}$ buffer, $\mathrm{pH}$ 6.0) from L. lactis subsp cremoris SK11 for periods up to $4 \mathrm{~h}$. For insulin B-chain, $240 \mu \mathrm{g}$ peptide was incubated with $9 \mu \mathrm{g}$ endopeptidase for up to $1 \mathrm{~h}$. Hydrolysis products were separated by HPLC and identified by amino acid sequence determination as described in Methods. Hydrolysed bonds are indicated by $\boldsymbol{\nabla}$. For comparison the bonds cleaved by the endopeptidase LEP-II from $L$. lactis subsp. cremoris H61 (Yan et al., 1987a) are shown by $\triangle$.

\begin{tabular}{|c|c|}
\hline Peptide & Sequence and peptide bond(s) hydrolysed \\
\hline Metenkephalin & $\begin{array}{c}\nabla \\
\text { Tyr-Gly-Gly - Phe-Met } \\
\triangle\end{array}$ \\
\hline Bradykinin & Arg-Pro-Pro-Gly - Phe-Ser-Pro-Phe-Arg \\
\hline Angiotensin & $\underset{\Delta}{\Delta} \underset{\Delta}{\Delta} \stackrel{\Delta}{\nabla^{-}}$ \\
\hline Insulin B-chain & Phe-Val-Asn-Gln-His-Leu-Cys-Gly-Ser-His - Leu-Val-Glu-Ala - Leu - Tyr - Leu- \\
\hline & 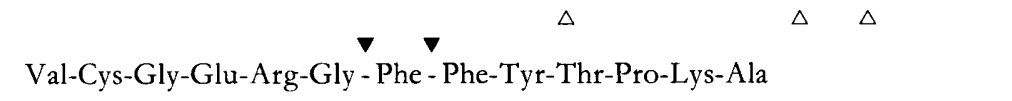 \\
\hline Neurotensin & $\underset{\text { pGlu-Leu - Tyr-Glu-Asn-Lys-Pro-Arg-Arg-Pro-Tyr-Ile-Leu }}{\nabla} \underset{\Delta}{\nabla}$ \\
\hline
\end{tabular}

$\mathrm{pH}$ and the use of angiotensin or metenkephalin as alternative substrates to bradykinin all yielded the same result, i.e. no more than $40 \%$ inhibition of enzyme activity. The complete inhibition by 1,10-phenanthroline and phosphoramidon suggests that the enzyme is indeed, like other lactococcal endopeptidases, a metalloenzyme, but the failure to achieve marked inhibition by EDTA suggests some conformational protection of the metal ion from this inhibitor. With respect to its insensitivity to inhibition by the serine proteinase inhibitor PMSF, and the thiol proteinase inhibitor $p C M B$, the endopeptidase from $L$. lactis subsp. cremoris SK11 is similar to that of other lactococcal endopeptidases and intracellular proteinases (Yan et al., 1987a; Muset et al., 1989; Desmazeaud \& Zevaco, 1976). The endopeptidase from L. lactis subsp. cremoris $\mathrm{Wg} 2$, on the other hand, was reported to be inhibited by $1 \mathrm{mM} p$ CMB (Tan et al., 1991) although the percentage inhibition was not stated.

\section{Substrate specificity}

The bonds hydrolysed in various hormone peptides are shown in Table 4, which also indicates the sites of hydrolysis found by Yan et al. (1987a) for LEP-II from $L$. lactis subsp. cremoris H61. It is evident that the specificity of action of endopeptidase from $L$. lactis subsp. cremoris SK11 in cleaving these five peptides is almost identical to that found for LEP-II (except for an additional three sites found only in the present study). Most of the bonds identified as cleavage sites in insulin B-chain in the present study were also found for the intracellular proteinase from L. lactis subsp. lactis NCDO 763 by Muset et al. (1989) and for an endopeptidase from $L$. lactis subsp. lactis bv. diacetylactis by Desmazeaud \& Zevaco (1976), although these two studies also reported a few additional cleavage sites. However, the cleavage patterns found in the present study are very different from those found for the endopeptidase LEP-I from the H61 strain (Yan et al., 1987b), which does not hydrolyse insulin B-chain and which hydrolyses neurotensin and bradykinin in a different manner. The bond specificity of the endopeptidase purified from $L$. lactis subsp. cremoris Wg2 (Tan et al., 1991) was not reported but that enzyme catalysed hydrolysis of neurotensin, metenkephalin, bradykinin and insulin B-chain (angiotensin was not investigated) and thus showed a similar spectrum of peptide susceptibility to hydrolysis to that of the enzyme purified in the present study. Inspection of the cleaved bonds (Table 4) reveals that the enzyme shows a strong preference for bonds in which a Leu or Phe residue occupies the P1' site (i.e. in the position immediately C-terminal to the cleaved bond). It thus has a specificity very similar to that of thermolysin. In fact, the particular bonds hydrolysed in insulin B-chain are virtually the same as those cleaved by thermolysin and various other neutral metalloproteases from a variety of microbial sources (Morihara, 1974). The only thermolysin-sensitive bond in B-insulin not identified as a cleavage site in the present study is the $\mathrm{His}_{5}-\mathrm{Leu}_{6}$ peptide bond.

\section{Hydrolysis of casein oligopeptides}

As found for other lactococcal endopeptidases (Yan et al., 1987a, b; Tan et al., 1991), the endopeptidase from $L$. lactis subsp. cremoris SK11 was not able to hydrolyse intact $\alpha$-, $\beta$ - or $\kappa$-caseins. However, it did catalyse hydrolysis of 
Table 5. Peptide bonds hydrolysed in casein oligopeptides by the endopeptidase from L. lactis subsp. cremoris SK11

Casein oligopeptides were generated by digesting $\beta$ - and $\kappa$-casein with cell envelope proteinases from L. lactis subsp. cremoris strains H2 and SK11 as described by Reid et al. (1991a, b). The peptides were isolated from the digest by reverse-phase HPLC and identified by the methods described previously (Reid $e$ al., 1991a). The casein peptides were incubated with purified endopeptidase (approx. $10 \mu \mathrm{g}$ ) for periods up to $24 \mathrm{~h}$. Samples were taken after various times and the peptide products were isolated by reverse-phase HPLC and identified by amino acid sequence analysis. Numbers in parentheses refer to the residue numbers in the amino acid sequence of the respective caseins. Peptides bonds hydrolysed are indicated by

\begin{tabular}{|c|c|}
\hline Peptide & Sequence and peptide bond(s) hydrolysed \\
\hline$k$-Casein $(161-169)$ & $\stackrel{\nabla}{\nabla}$ \\
\hline $\begin{array}{c}\beta-\text { Casein }(1-209 ; \text { total } \\
\text { sequence })\end{array}$ & Not hydrolysed \\
\hline$(47-52)$ & Asp-Lys-Ile-His-Pro-Phe; not hydrolysed \\
\hline$(166-175)$ & Ser-Gln-Ser-Lys-Val-Leu-Pro-Val-Pro-Gln; not hydrolysed \\
\hline $\begin{array}{l}(176-182) \\
(183-193)\end{array}$ & $\begin{array}{l}\text { Lys-Ala-Val-Pro-Tyr-Pro-Gln; not hydrolysed } \\
\text { Arg-Asp-Met-Pro-Ile-Gln-Ala - Phe-Leu - Leu-Tyr }\end{array}$ \\
\hline$(194-209)$ & Gln-Glu-Pro-Val-Leu-Gly-Pro-Val-Arg-Gly-Pro-Phe-Pro-Ile-Ile-Val \\
\hline
\end{tabular}

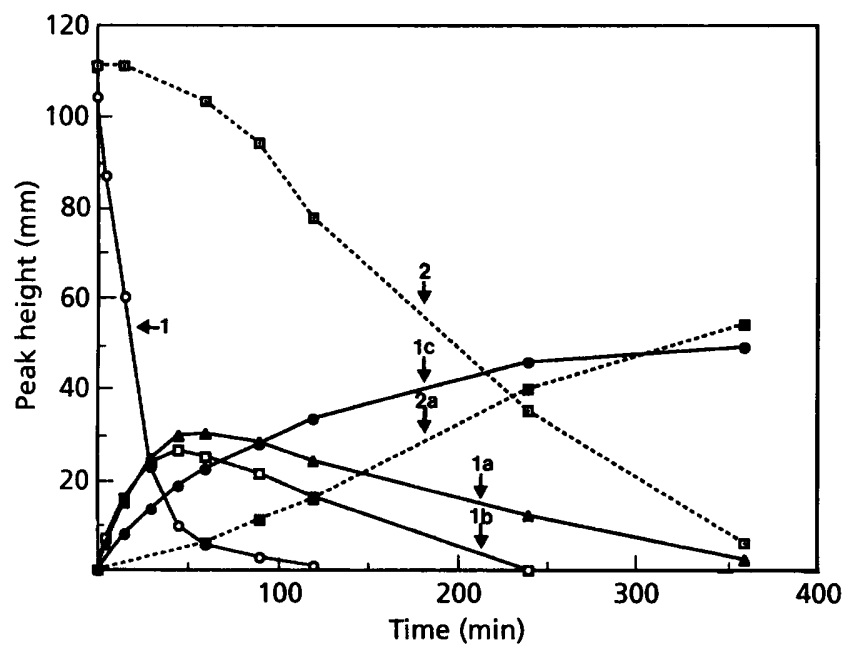

Fig. 2. Time course of hydrolysis by the endopeptidase of two oligopeptides derived from $\beta$-casein by action of the cell envelope proteinase from $L$. lactis subsp. cremoris $\mathrm{H} 2$. 1, The peptide Arg-Asp-Met-Pro-lle-Gln-Ala-Phe-Leu-Leu-Tyr ( Arg $_{183}$ Tyr $_{193}$ in $\beta$-casein). 1a-1c, Hydrolysis products of peptide 1: 1a, $\mathrm{Phe}_{190}-\mathrm{Tyr}_{193} ; 1 \mathrm{~b}, \mathrm{Arg}_{183}-\mathrm{Ala}_{189} ; 1 \mathrm{C}$, the tetrapeptide $\mathrm{Arg}_{183}-\mathrm{PrO}_{186}$ plus the dipeptide $\mathrm{Leu}_{192}-\mathrm{Tyr}_{193}$ (these two peptides have the same retention time in the HPLC system used). 2, The peptide Gln-Glu-Pro-Val-Leu-Gly-Pro-Val-Arg-GlyPro-Phe-Pro-lle-lle-Val ( $\mathrm{Gln}_{194}-\mathrm{Val}_{209}$ in $\beta$-casein). 2a, Hydrolysis product of peptide 2: $\mathrm{Gln}_{194}-\mathrm{PrO}_{206}$.

some oligopeptides derived from these caseins (Table 5). The peptides shown in Table 5 were isolated from digests obtained by incubating the intact $\beta$ - and $\kappa$-caseins with purified cell-envelope-associated proteinases from either L. lactis subsp. cremoris SK11 (a $\mathrm{P}_{\mathrm{III}}$-type proteinaseproducing strain) or $L$. lactis subsp. cremoris $\mathrm{H} 2\left(\mathrm{a}_{\mathrm{I}}\right.$-type proteinase-producing strain). The $\kappa$-casein $(161-169)$ peptide, a major product of $\kappa$-casein digestion by the $\mathrm{P}_{\mathrm{III}}{ }^{-}$ type proteinase at the earliest digestion times (J. R. Reid, T. Coolbear \& G. G. Pritchard, unpublished), is readily hydrolysed by the endopeptidase at the $\mathrm{Gln}_{163}-\mathrm{Val}_{164}$ bond. Of the four major peptides generated during the initial stage of hydrolysis of $\beta$-casein by the $\mathrm{P}_{\mathrm{I}}$-type lactococcal cell envelope-associated proteinase (Reid et al., 1991b), the peptides $\mathrm{Arg}_{183}-\mathrm{Tyr}_{193}$ and $\mathrm{Gln}_{194}-\mathrm{Val}_{209}$ were hydrolysed by the endopeptidase at one or more of the peptide bonds with hydrophobic residues in the $\mathrm{P} 1^{\prime}$ position (Table 5). There was, however, a significant difference in the rate of hydrolysis of these two peptides. At identical enzyme concentrations, the peptide $\mathrm{Arg}_{183}-\mathrm{Tyr}_{193}$ was almost completely degraded after $1 \mathrm{~h}$ whereas the C-terminal $\beta$-casein peptide $\mathrm{Gln}_{194}-\mathrm{Val}_{209}$ was more slowly hydrolysed over a period of $6 \mathrm{~h}$ (Fig. 2). Hydrolysis of the former peptide $\left(\mathrm{Arg}_{183}-\mathrm{Tyr}_{193}\right)$ occurred initially at the $\mathrm{Ala}_{189}-\mathrm{Phe}_{190}$ bond, leading to the transient accumulation of the heptapeptide Arg-Asp-MetPro-Ile-Gln-Ala and the tetrapeptide Phe-Leu-Leu-Tyr (Fig. 2). Both of these initial peptide products were subsequently degraded to smaller peptides at the bonds indicated in Table 5 . The $\mathrm{C}$-terminal $\beta$-casein peptide $\left(\mathrm{Gln}_{194}-\mathrm{Val}_{209}\right)$ was hydrolysed only at the $\mathrm{Pro}_{206}-\mathrm{Ile}_{207}$ bond. The large $\mathrm{N}$-terminal product of this hydrolysis $\left(\mathrm{Gln}_{194}-\mathrm{Pro}_{206}\right)$ accumulated and was still present as a major product after $24 \mathrm{~h}$ digestion. The relative resistance of this peptide to hydrolysis is surprising in view of the presence of hydrophobic residues in the sequence which 
Table 6. Subcellular distribution of endopeptidase activity in L. lactis subsp. cremoris SK11

Percentage distribution of total cellular activity of endopeptidase, lysine anmopeptidase and fructose-1,6-bisphosphate aldolase activits between different cellular fractions obtained using the procedure of (row et al (1993)

\begin{tabular}{|lccc|}
\hline Enzyme & $\begin{array}{c}\text { Cell wall } \\
\text { lysate } \\
(\%)\end{array}$ & $\begin{array}{c}\text { Cytoplasmic } \\
\text { fraction } \\
(\%)\end{array}$ & $\begin{array}{c}\text { Particulate } \\
\text { fraction } \\
(\%)\end{array}$ \\
\hline $\begin{array}{l}\text { Lysinc aminopeptidase } \\
\text { Frucsuse bisplosphate } \\
\text { aldolase }\end{array}$ & $0 \cdot 2$ & $99 \cdot 1$ & 0.7 \\
Endripeptidasc & $1 \cdot 4$ & $99 \cdot 0$ & 0.7 \\
\hline
\end{tabular}

could indicate likely cleavage sites, suggesting that conformational factors as well as the primary sequence determine the susceptibility to hydrolysis. The peptides from this region of $\beta$-cascin have been shown to be extremely bitter (Shinoda to al., 1985) and have been implicated as contributing to the bitter flavour defect of cheese (Visser et al., 1983). Other early products of $\mathrm{P}_{\mathrm{I}}$-type cell-envelope-associated proteinase action on $\beta$-cascin, namely the peptides Lys $_{176}-G \ln _{182}$, a series of three overlapping, not easily separated, peptides from the sequence $\operatorname{Ser}_{166}(i)_{175}$ and also the hexapeptide Asp $_{1}$ : Phe $_{52}$, an early product of $P_{111}$ type proteinase action (Reid et al., 1991b), were not hydrolysed by the endopeptidase even after $24 \mathrm{~h}$ incubation.

\section{Cellular location of endopeptidase activity}

Harvested cells were separated into three subcellular fractions designated 'cell-wall lysate', 'cytoplasmic' and 'particulate' fractions using the procedure described by Crow et al. (1993). The cell-wall lysate fraction contains proteins, such as the cell-cnvelope-associated proteinase, released from the cell wall by treatment with the lytic enzymes, lysozyme and mutanolysin. 'The cytoplasmic fraction contains soluble (and possibly loosely membranebound) proteins released into the supernatant when spheroplasts are lysed and centrifuged, while the particulate fraction contains proteins and other materials tightly bound to the cell wall and membrane (Coolbear et al., 1992b; Crow et al., 1993). The distribution of endopeptidase activity between the three fractions was compared with that of the cytoplasmic marker enzyme, fructose-1,6-bisphosphate aldolase, and of the enzyme lysine aminopeptidase which, on the basis of current evidence, also has a cytoplasmic location (Tan $t$ t al., 1992 ; Exterkate et al., 1992). The results of the present study (Table 6) clearly indicate that endopeptidase (bradykinindegrading) activity is located in the cytoplasm fraction. The endopeptidase isolated from $I$. lactis subsp. cremoris Wg2 was also shown, by immunogold labelling and antibody binding to subcellular fractions, to be located predominantly in the cytoplasm (Tan et al., 1992). In the recently determined nucleotide sequence of the endo- peptidase gene, pepO, from $L$. lactis subsp. cremoris P8-2-47 (Mierau et al., 1993), the translation start site corresponds to the codon specifying the $\mathbf{N}$-terminus of the mature protein, showing that no signal sequence characteristic of membranc-translocated protcins is present; this provides further confirmation of the intracellular location.

\section{Concluding remarks}

The endopeptidase purified in the present study is probably closely related to, or identical with, the $70 \mathrm{kDa}$ enzymes from the $L$. lactis subsp. cremoris strains Wg2 (Tan et al., 1991), C13 (Baankreis, 1992) and P8-2-47 (Mierau et al., 1993). It also resembles the endopeptidase I.FP-II from L. lactis subsp. cremori. H61 (Yan et al., $1987 \mathrm{a}$ ) in its specificity of hydrolysis of five different oligopeptides (see lable 4) but its molecular mass and $\mathbf{N}$ terminal amino acid sequence clearly distinguish it from the latter enzyme. This raises the question of the relationship of the endopeptidase L-F.P-Il from L. lactis subsp. cremoris $\mathrm{H61}$ to the other recently studied lactococcal endopeptidases. It would seem rather improbable that a totally different enzyme, with identical specificity to that of the $70 \mathrm{kDa}$ enzyme purified in the present study, exists in L. lactis subsp. cremoris H61, especially since Tan et al. (1991) showed, using an antibody raised to the purified endopeptidase from the $\mathbb{W} g 2$ strain, that a $70 \mathrm{kDa}$ endopeptidase was present in the H61 strain.

The specificity properties of the endopeptidase from I. lactis subsp. cremoris SK11 (Table 4) suggest that it could potentially contribute to the degradation of $\beta$-casein oligopeptides with a high content of hydrophobic residues. The hydrophobic C-terminal peptide of $\beta$-casein (Pro ${ }_{196} \mathrm{Val}_{207}$ ) has been shown to be very bitter (Shinoda et al., 1985). This peptide was slowly hydrolysed by the endopeptidase but only at one peptide bond, leaving a relatively large hydrophobic fragment undegraded. The endopeptidase $\mathrm{N}$ (OP from I. lactis subsp. cremoris C.13 was also found to hydrolyse this peptide (Baankreis, 1992). However, the cytoplasmic location of the endopeptidase would suggest that it plays only a very limited, if any, role in the cascin degradation pathway in the intact cell, unless the recently described oligopeptide transport system (Kunji et al., 1993) is capable of transporting peptides larger than the previously suggested upper size limit (6 to 7 amino acid residues) for transport across the cell membrane (Rice et al., 1978; Law, 1978). Indeed, Micrau et al. (1993), using gene disruption to obtain a pepO mutant lacking this endopeptidase, showed that the growth and rate of acid production of this mutant were identical to the parent $p e p \mathrm{O}^{+}$strain, demonstrating clearly that this endopeptidase is not essential for lactococcal growth in milk. It may, however, play a significant role in the ripening phase of cheese manufacture if it is liberated by starter lactococci into the cheese curd.

\section{ACKNOWLEDGEMENTS}

This rescarch was supported in part by the Foundation for Research, Science and Technology, NZ. A grant from the Massey Ciniversity Research Fund is also acknowledged. 


\section{REFERENCES}

Baankreis, R. (1992). The role of lactococcal peptidases in cheese ripening. PhD thesis, University of Amsterdam, The Netherlands.

Booth, M., Donnelly, W. J., Ni Fhaolain, I., Jennings, P. V. \& O'Cuinn, G. (1990). Proline-specific peptidases of Streptococcus cremoris AM2. J Dairy Res 57, 79-88.

Coolbear, T., Reid, J. R. \& Pritchard, G. G. (1992a). Stability and specificity of the cell wall-associated proteinase from Lactococcus lactis subsp. cremoris $\mathrm{H} 2$ released by treatment with lysozyme in the presence of calcium ions. Appl Environ Microbiol 58, 3263-3270.

Coolbear, T., Holland, R. \& Crow, V. L. (1992b). Parameters affecting the release of cell surface components and lysis of Lactococcus lactis subsp. cremoris. Int Dairy J 2, 213-232.

Crow, V. L. \& Thomas, T. D. (1982). D-Tagatose 1,6-diphosphate aldolase from lactic streptococci; purification, properties and use in measuring intracellular tagatose 1,6-diphosphate. J Bacteriol 151, 600-608.

Crow, V. L., Holland, R. \& Coolbear, T. (1993). Comparison of subcellular fractionation methods for Lactococcus lactis subsp. lactis and L. lactis subsp. cremoris. Int Dairy J 3, 599-611.

Desmazeaud, M. J. \& Zevaco, C. (1976). General properties and substrate specificity of an intracellular neutral protease from Streptococcus diacetylactis. Ann Biol Anim Biocbim Biophys 16, 851-868.

Exterkate, F. A., De Jong, M., de Veer, G. J. C. M. \& Baankreis, R. (1992). Location and characterization of aminopeptidase $N$ in Lactococcus lactis subsp. cremoris HP. Appl Microbiol Biotechnol 37, 46-54.

Kok, J. (1990). Genetics of the proteolytic system of lactic acid bacteria. FEMS Microbiol Rev 87, 15-42.

Kunji, E. R. S., Smid, E. J., Plapp, R., Poolman, B. \& Konings, W. N. (1993). Di-tripeptides and oligopeptides are taken up via distinct transport mechanisms in Lactococcus lactis. J Bacteriol 175, 2052-2059.

Laemmli, U. K. (1970). Cleavage of structural proteins during the assembly of the head of bacteriophage T4. Nature 227, 680-685.

Law, B. A. (1978). Peptide utilization by group $\mathrm{N}$ streptococci. J Gen Microbiol 105, 113-118.

Lloyd, R. J. \& Pritchard, G. G. (1991). Characterization of X-prolyl dipeptidyl aminopeptidase from Lactococcus lactis subsp. lactis. J Gen Microbiol 137, 49-55.

Mierau, I., Tan, P. S. T., Haandrikman, A. J., Kok, J., Leenhouts, K. J., Konings, W. N. \& Venema, G. (1993). Cloning and sequencing of the gene for a lactococcal endopeptidase, an enzyme with sequence similarity to mammalian enkephalinase. J Bacteriol 175, 2087-2096.

Monnet, V., Bockelmann, W., Gripon, J.-C. \& Teuber, M. (1989). Comparison of cell wall proteinases from Lactococcus lactis subsp. cremoris AC1 and Lactococcus lactis subsp. lactis NCDO 763. II. Specificity towards bovine $\beta$-casein. Appl Microbiol Biotecbnol 31, $112-118$

Monnet, V., Ley, J. P. \& Gonzalez, S. (1992). Substrate specificity of the cell envelope-located proteinase of Lactococcus lactis subsp. lactis NCDO 763. Int Biochem 24, 707-718.

Morihara, K. (1974). Comparative specificity of microbial proteases. Adv Enzymol 41, 179-243.

Muset, G., Monnet, V. \& Gripon, J.-C. (1989). Intracellular proteinase of Lactococcus lactis subsp. lactis NCDO 763. J Dairy Res 56, 765-778.

Nardi, M., Chopin, M.-C., Chopin, A., Cals, M.-M. \& Gripon, J.-C.
(1991). Cloning and DNA sequence analysis of X-prolyl dipeptidyl aminopeptidase from Lactococcus lactis subsp. lactis NCDO 763. Appl Environ Microbiol 57, 45-50.

Pritchard, G. G. \& Coolbear, T. (1993). The physiology and biochemistry of the proteolytic system in lactic acid bacteria. FEMS Microbiol Rev 12, 179-206.

Reid, J. R., Moore, C. H., Midwinter, G. G. \& Pritchard, G. G. (1991a). Action of a cell wall proteinase from Lactococcus lactis subsp. cremoris SK11 on bovine $\alpha_{\mathrm{s} 1}$-casein. Appl Microbiol Biotechnol 35, 222-227.

Reid, J. R., Ng, K. H., Moore, C. H., Coolbear, T. \& Pritchard, G. G. (1991b). Comparison of bovine $\beta$-casein hydrolysis by $\mathrm{P}_{\mathrm{I}}$ and $\mathrm{P}_{\mathrm{III}^{-}}$ type proteinases from Lactococcus lactis subsp. cremoris. Appl Microbiol Biotechnol 36, 344-351.

Rice, G. H., Stewart, F. C., Hillier, A. J. \& Jago, G. R. (1978). The uptake of amino acids and peptides by Streptococcus lactis. J Dairy Res 45, 93-107.

Shinoda, I., Fushimi, A., Kato, H., Okai, H. \& Fukui, S. (1985). Bitter taste of synthetic $\mathrm{C}$-terminal tetradecapeptide of bovine $\beta$-casein, H-Pro ${ }^{196}$-Val-Leu-Gly-Pro-Val-Arg-Gly-Pro-Phe-Pro-Ile-Ile$\mathrm{Val}^{209}-\mathrm{OH}$ and its related peptides. Agric Biol Chem 49, 2587-2596.

Smid, E. J., Poolman, B. \& Konings, W. N. (1991). Casein utilization by lactococci. Appl Environ Microbiol 57, 2447-2452.

Smith, P. K., Krohn, R. I., Hermanson, G. T., Mallia, A. K., Gartner, F. H., Provenzano, M. D., Fujimoto, F. K., Goeke, N. M., Olson, B. J. \& Klenk, D. C. (1985). Measurement of protein using bicinchoninic acid. Anal Biochem 150, 76-85.

Tan, P. S. T., Pos, K. M. \& Konings, W. N. (1991). Purification and characterization of an endopeptidase from Lactococcus lactis subsp. cremoris Wg2. Appl Environ Microbiol 57, 3593-3599.

Tan, P. S. T., Chapot-Chartier, M.-P., Pos, K. M., Rousseau, M., Boquien, C.-Y., Gripon, J.-C. \& Konings, W. N. (1992). Localization of peptidases in lactococci. Appl Environ Microbiol 58, 285-290.

Tan, P. S. T., Poolman, B. \& Konings, W. N. (1993). The proteolytic enzymes of Lactococcus lactis. J Dairy Res 60, 269-286.

Visser, S., Slangen, K. J., Hup, G. \& Stadhouders, J. (1983). Bitter flavour in cheese. 3. Comparative gel-chromatographic analysis of hydrophobic peptide fractions from twelve Gouda-type cheeses and identification of bitter peptides isolated from a cheese made with Streptococcus cremoris HP. Neth Milk Dairy J 37, 181-192.

Visser, S., Slangen, C. J., Exterkate, F. A. \& de Veer, G. J. C. M. (1988). Action of a cell wall proteinase $\left(\mathrm{P}_{\mathrm{I}}\right)$ from Streptococcus cremoris HP on bovine $\beta$-casein. Appl Microbiol Biotechnol 29, 61-66.

Visser, S., Robben, A. J. P. M. \& Slangen, C. J. (1991). Specificity of a cell-envelope-located proteinase $\left[\mathrm{P}_{\mathrm{II}}\right.$-type] from Lactococcus lactis subsp. cremoris AM1 in its action on bovine $\beta$-casein. Appl Microbiol Biotechnol 35, 477-483.

Yan, T.-R., Azuma, N., Kaminogawa, S. \& Yamauchi, K. (1987a). Purification and characterization of a novel metalloendopeptidase from Streptococcus cremoris H61. Eur J Biochem 163, 259-265.

Yan, T.-R., Azuma, N., Kaminogawa, S. \& Yamauchi, K. (1987b). Purification and characterization of a substrate-size recognising metalloendopeptidase from Streptococcus cremoris H61. Appl Environ Microbiol 53, 2296-2302.

Zevaco, C. \& Desmazeaud, M. (1980). Hydrolysis of $\beta$-casein and peptides by intracellular neutral protease of Streptococcus diacetylactis. J Dairy Sci 63, 15-24.

Received 1 September 1993; revised 19 October 1993; accepted 27 October 1993. 